\title{
Promosi dan pemasaran pariwisata objek wisata Tirta Sinongko dalam upaya menarik wisatawan
}

\author{
Novita Prastiani ${ }^{1}$, Rhesa Zuhriya Briyan Pratiwi ${ }^{2}$ \\ ${ }^{1,2}$ Institut Agama Islam Negeri (IAIN) Surakarta, Sukoharjo, Indonesia
}

\begin{abstract}
ABSTRAK
Maraknya sejumlah objek wisata lokal di beberapa wilayah Indonesia menjadi penanda terhadap pentingnya aset pariwisata sebuah kota. Konsep pariwisata lokal yang ada merujuk pada pariwisata daerah yang identik budaya masyarakat setempat. Secara tidak langsung, adanya objek wisata lokal mampu memberikan ciri khas bagi sebuah daerah karena merefleksikan hasil cipta, karsa, dan karya atas budaya masyarakat yang berbeda dengan wilayah lainnya. Salah satu indikator yang menunjukkan bahwa objek wisata dinyatakan berhasil adalah dengan banyaknya jumlah wisatawan yang hadir dan mengunjungi lokasi wisata. Dalam hal ini, banyak aspek dapat mempengaruhi bagaimana preferensi orang untuk mengunjungi objek wisata, salah satunya Tirta Sinongko. Tirta Sinongko adalah objek wisata dengan konsep wisata pemandian alam yang terletak di wilayah Ceper, Kabupaten Klaten. Tujuan dari penelitian ini adalah untuk menggambarkan bagaimana komunikasi pemasaran dilakukan oleh Pemerintah Desa Pokak, Ceper, dalam mengelola Tirta Sinongko untuk menarik wisatawan, terutama melalui BUMDes sebagai manajer operasionalnya. Penelitian ini dilakukan secara kualitatif dengan mengumpulkan data melalui observasi, wawancara mendalam, dan dokumentasi. Untuk hasil penelitian, disimpulkan bahwa komunikasi pemasaran dari Tirta Sinongko dilakukan melalui tiga bentuk strategi utama, yaitu: promosi online yang dilakukan melalui media sosial; penyelenggaraan event khusus untuk meningkatkan daya kunjung dan atensi wisatawan; dan penjualan personal yang dilakukan melalui komunikasi langsung dengan para wisatawan. Ketiga kegiatan tersebut dilakukan terus menerus oleh Pemerintah Desa dan pengelola untuk meningkatkan wisatawan di Tirta Sinongko.
\end{abstract}

Kata-kata Kunci: Komunikasi pemasaran; objek wisata; pariwisata; Tirta Sinongko; wisatawan

\section{Promotion and marketing tourism of Tirta Sinongko tourism object in effort of attracting tourists}

\begin{abstract}
The rising number of local tourism objects in several regions of Indonesia marks the importance of a city's tourism assets. The existing concept of local tourism refers to regional tourism, which is identical to the culture of the local community. The existence of a local tourist attraction, indirectly, can give a characteristic to a particular area as it reflects creation, initiative, and work on a culture of a society that is different from other regions. One indicator that shows that a tourist attraction is declared successful is the large number of tourists who attend and visit tourist sites. In this case, many aspects can influence how people's preferences to visit attractions, one of which is Tirta Sinongko. Tirta Sinongko is a tourist attraction with the concept of a natural bathing tour located in the Ceper region, Klaten Regency. The purpose of this study is to describe how marketing communication to attract tourists is carried out by the Pokak Village Government in managing Tirta Sinongko, primarily through BUMDes as its operational manager. This research was conducted qualitatively by collecting data through observation, in-depth interviews, and documentation. The results of the study conclude that marketing communication was carried out through three main forms of strategy, namely: online promotion carried out through social media, organizing special events to increase the visiting intention and attention of tourists, and personal sales made through direct communication with tourists. The three activities are carried out continuously by the Village Government to increase the number of tourists.
\end{abstract}

Keywords: Marketing communication; Tirta Sinongko; tourism; tourist; tourist attraction

Korespondensi: Novita Prastiani, S.Sos. IAIN Surakarta. Jalan Pandawa, Pucangan, Kartasura, Sukoharjo, Jawa Tengah 57168. Email: novitaprastiani@gmail.com 


\section{PENDAHULUAN}

Perkembangan sejumlah lokasi wisata di Kabupaten Klaten pada dasarnya merujuk pada tiga bentuk wisata, yakni wisata alam, wisata buatan, dan wisata budaya. Sebut saja salah satunya Tirta Sinongko. Objek ini merupakan objek wisata yang berbentuk pemandian alami dan mengutamakan keasrian lokasi yang natural. Adapun pengelolaan objek wisata yang terletak di Desa Pokak, Kecamatan Ceper, Kabupaten Klaten ini pada dasarnya dikelola oleh Pemerintah Desa bersama masyarakat setempat, yang mana terdiri dari kelompok paguyuban warga serta karang taruna. Terkait hal tersebut, guna membantu operasional pengelolaan Tirta Sinongko, Pemerintah Desa selanjutnya membentuk Badan Usaha Milik Desa (BUMDes) sebagai upaya untuk mengelola Tirta Sinongko agar lebih terorganisir.

Salah satu keunikan dari objek wisata Tirta Sinongko yang jarang ditemui pada objek wisata sejenis lainnya adalah mengenai adanya tradisi kenduri yang dilaksanakan setelah salat Jumat, tepatnya pada hari Wage, setiap setahun sekali, oleh masyarakat di Tirta Sinongko. Kenduri ini dilakukan sebagai wujud syukur kepada Tuhan Yang Maha Esa atas limpahan mata air sendang Sinongko Lanang dan Sinongko Wadon, dimana sumber air tersebut juga digunakan untuk pengairan pada wilayah sekitarnya.
Adapun sejumlah promosi yang telah dilakukan mengenai Tirta Sinongko, antara lain dilakukan melalui media sosial Facebook dan Instagram. Hal ini dapat ditilik melalui salah satu pemberitaan dalam portal berita online yang menobatkan Tirta Sinongko sebagai salah satu tujuan wisata terindah di Kabupaten Klaten (Onlineindopos.id, 2018). Namun demikian, sisi lain yang dirasa masih kurang dalam kondisi Tirta Sinongko adalah keberadaan wisatawan yang dapat dikatakan lebih rendah daripada objek wisata sejenis lainnya di wilayah Klaten.

Penelitian terdahulu tentang bagaimana strategi bauran komunikasi pemasaran yang dilakukan objek wisata Ponggok melalui Pemerintah Desa sebagai pengelolanya, terutama dalam menarik wisatawan yang berkunjung. Dalam penelitiannya, Ponggok dinyatakan memiliki positioning sebagai objek wisata yang sedang booming melalui wahana baru diving dan snorkling. Kedua wahana tersebut menjadi salah satu aspek penting dalam komunikasi pemasaran ponggok agar menarik perhatian wisatawan. Dalam konteks ini, Ponggok termasuk objek wisata yang cukup diperhitungkan di wilayah Klaten, sekaligus memiliki citra yang lebih terkenal dibanding dengan Tirta Sinongko (Saroh Ganik Haryati, 2015).

Perlunya meningkatkan kuantitas pengunjung dalam objek wisata Tirta Sinongko 
ini dapat dilakukan melalui optimalisasi penyebaran informasi serta promosi kepada para wisatawan. Selama ini, penyebaran tiket di Tirta Sinongko dirasa kurang efektif karena hanya dilakukan di beberapa wahana saja. Bahkan, ada salah satu wahana atau objek dalam Tirta Sinongko yang tidak terkena biaya retribusi sehingga pengunjung lebih memilih pada wahana tersebut dibandingkan dengan lainnya. Pada akhirnya, hal ini berakibat pada kuantitas jumlah pengunjung yang datang ke Tirta Sinongko.

Berdasarkan data yang diperoleh, tercatat jumlah pengunjung di tahun 2016 adalah sebanyak 1000 orang per bulan. Lalu pada tahun 2017, jumlah pengunjung ada sebanyak 1400 orang dalam setiap bulannya. Sekilas, terjadi peningkatan dalam kunjungan wisatawan. Namun demikian, hal ini belum dapat dikatakan menjadi tolak ukur utama untuk menentukan apakah Tirta Sinongko benarbenar menjadi objek wisata yang sudah optimal dalam melakukan promosi dan pemasaran. Hal ini dikarenakan berdasarkan observasi pra penelitian, jumlah pengunjung tergolong masing rendah apabila dibandingkan dengan beberapa objek wisata lainnya yang lebih dahulu dibangun dan memiliki positioning lain dibandingkan dengan Tirta Sinongko. Namun demikian, objek wisata Tirta Sinongko pada dasarnya memiliki potensi untuk terus berkembang, terutama dalam pengelolaannya sehingga dirasa objek wisata ini memiliki keunikan yang lebih untuk diteliti yakni melalui upaya komunikasi pemasaran yang dilakukan. Membahas mengenai komunikasi pemasaran, salah satu penelitian terdahulu mengenai strategi komunikasi pemasaran Pemerintah Desa Kalisari terhadap pengenalan potensi wisata desa. Dalam hal ini, sama-sama berangkat dari konsep desa wisata, kedua penelitian ini membahas tentang bagaimana pentingnya komunikasi pemasaran diperlukan dalam pengelolaan objek wisata berbasis desa. Namun demikian, penelitian Fadli cenderung menggunakan analisis SWOT yang dilakukan pemerintah desa dalam mempromosikan potensi desa. Di sisi lain, penelitian ini lebih merujuk pada diperlukannya strategi komunikasi pemasaran terhadap objek wisata Tirta Sinongko, sekaligus mengidentifikasikan poin pemasaran apa yang dapat dikembangkan secara lebih optimal guna menarik wisatawan untuk outputnya (Fadli, 2017).

Pentingnya kegiatan pemasaran yang terimplementasi melalui komunikasi pemasaran hendaknya menjadi salah satu alternatif yang dapat digunakan untuk menjadikan sebuah objek wisata menjadi lebih menarik banyak perhatian wisatawan. Tujuan komunikasi pemasaran dapat diidentifikasikan menjadi tiga hal, yaitu: 1) menyebarkan informasi; 2) mempengaruhi 
seseorang untuk membeli atau beralih merek; 3) mengingatkan seseorang untuk melakukan pembelian ulang. Ketiga pernyataan di atas dapat merujuk pada bagaimana komunikasi pemasaran mengacu pada tiga aspek utama komunikasi, yakni informatif, persuasif, dan reminder (Suryanto, 2015).

Bagaimana pemasaran berkenaan dengan komunikasi yang bersifat persuasif, salah satunya dapat dikaitkan dengan adanya keputusan membeli bagi pelanggan. Hal ini dapat ditinjau melalui tulisan Krestiawan Wibowo yang berbicara tentang adanya Pengaruh Kualitas Produk, Harga dan Promosi Terhadap Keputusan Pembelian Permen Tolak Angin Di Semarang. Tulisan ini menjelaskan tentang adanya pengaruh antara aspek kualitas produk, harga, yang disertai dengan upaya promosi dalam meningkatkan keputusan pembelian terhadap produk permen Tolak Angin di wilayah Semarang (Wibowo, Waluyo, \& Listyorini, 2013).

Aktivitas dalam komunikasi pemasaran pada akhirnya berupaya untuk mengubah sikap dan kecenderungan konsumen untuk beralih pada apa yang menjadi tujuan dari pihak yang melakukan pemasaran. Pemasaran dalam konteks ini berkenaan pula dengan aspek promosi, dimana konsep promosi pada dasarnya dinyatakan sebagai penunjang yang bertujuan untuk meningkatkan proses pembelian. Promosi juga dimaknai sebagai komunikasi atas informasi yang dikemukakan oleh penjual kepada pembeli yang bertujuan untuk mengubah sikap dan perilaku pembeli, yang pada awalnya tidak mengenal atau kurang mengenal, selanjutnya menjadi mengenal, perhatian, dan mau untuk membeli atau bahkan selalu mengingat produk (Saladin, 2002).

Proses komunikasi pemasaran memuat sebuah model yang berawal dari pemasaran bersifat linear, yakni inisiatif pertama pada interaksi yang dilakukan oleh pemilik brand (jenama). Aktivitas interaksi ini kemudian diterima oleh target pasar dan direspon sebagai bentuk umpan balik (Yunus, 2019). Konsep inilah yang secara tidak langsung mendasari bagaimana komunikasi pemasaran penting untuk dilakukan pada sejumlah sebuah objek wisata, tak terkecuali Tirta Sinongko.

Merujuk uraian di atas, berlangsungnya komunikasi pemasaran turut diiringi dengan Peraturan Daerah Kabupaten Klaten tahun 2014 mengenai rencana induk pembangunan pariwisata Kabupaten Klaten. Adapun arah kebijakan yang dilakukan untuk pemasaran pariwisata Kabupaten Klaten, salah satunya adalah dengan mengutamakan kegiatan promosi (Pemda Klaten, 2014).

Promosi sebagai bagian dari proses penjenamaan dapat diukur dari bagaimana umpan balik atas respon customer (pasar). 
bukti adanya respon ataupun umpan balik yang merujuk pada beberapa hal, antara lain adalah: 1) customer engagement; 2) permission engagement; dan 3) content marketing. Secara operasional, dalam sebuah objek wisata misalnya, umpan balik sebagai respon pasar secara sederhana salah satunya dapat dilihat dari kuantitas wisatawan yang berkunjung. Hal ini mampu diartikan sebagai bentuk customer engagement yang memungkinkan adanya ikatan antara jenama objek wisata dengan wisatawan sehingga selanjutnya mereka melakukan interaksi langsung atas dasar ketertarikan dengan objek wisata yang dikunjungi guna memeroleh kepuasan (satisfaction) (Chaffey \& Ellis-Chadwick,2012).

Berdasarkan uraian di atas, dapat dikatakan Tirta Sinongko memiliki aspek menarik untuk diteliti dibandingkan objek wisata yang lainnya. Namun, permasalahan kuantitas wisatawan yang berkunjung masih menjadi problem yang harus diselesaikan, terutama melalui bagaimana strategi komunikasi pemasaran yang harus dilakukan. Dengan demikian, penting untuk dikaji lebih lanjut bagaimana komunikasi pemasaran yang dilakukan Pemerintah Desa melalui BUMDes terhadap objek wisata Tirta Sinongko dalam upaya menarik wisatawan. Lebih lanjut, secara khusus penelitian ini bertujuan untuk menggambarkan strategi perencanaan dan pelaksanaan komunikasi pemasaran agar kemudian dapat dioptimalisasikan guna memperoleh output berupa peningkatan jumlah wisatawan di objek wisata Tirta Sinongko.

\section{METODE PENELITIAN}

Penelitian ini menggunakan pendekatan kualitatif, terutama melalui proses pengamatan, wawancara, serta telaah dokumen yang dikerjakan secara deskriptif. Penelitian kualitatif memiliki desain penelitian yang bersifat umum, fleksibel, dan berkembang selama proses penelitian. Dengan demikian, penelitian jenis ini digunakan untuk memperoleh data yang sifatnya lebih mendalam dan kasuistik sehingga tidak merujuk pada generalisasi atas simpulan yang diperoleh (Sugiyono, 2018).

Lokasi penelitian yang diambil adalah objek wisata Tirta Sinongko yang berlokasi di Desa Pokak, Kecamatan Ceper, Kabupaten Klaten. Sesuai dengan pendekatan yang digunakan, teknik pengumpulan data pertama dilakukan melalui observasi. Observasi adalah kegiatan yang berkenaan dengan pemusatan perhatian pada objek tertentu dengan menggunakan panca indera yang dimiliki (Gunawan, 2013).

Pengumpulan data dilakukan dalam bentuk wawancara mendalam, dimana wawancara ini dilakukan kepada: 1) Kepala Desa Pokak sebagai penanggung jawab objek wisata; 2) Koordinator BUMDes selaku pengelola wisata; 3) Anggota 
BUMDes sebagai pelaksana operasional wisata sekaligus perwakilan dari masyarakat. Lebih lanjut, wawancara dilakukan dengan panduan wawancara, dengan jenis pertanyaan terbuka yang bersifat luas dan memberikan kebebasan terhadap informan untuk menyampaikan informasi secara mendalam (Herdiansyah \& Haris, 2015). Terakhir, pengumpulan data dilakukan dengan dokumentasi melalui sejumlah dokumen yang relevan dengan topik penelitian.

Guna menguji keabsahan data, dilakukan triangulasi data jenis sumber. Patton menyatakan bahwa triangulasi sumber (data) adalah teknik yang digunakan untuk membandingkan dan mengecek kembali derajat kepercayaan informasi melalui sumber-sumber yang berbeda (Kriyantono, 2006) Selanjutnya, untuk teknik analisis data dilakukan secara interaktif, dimana teknik ini terdiri dari reduksi data, penyajian data, serta penarikan kesimpulan atau verifikasi (Gunawan, 2013).

\section{HASIL DAN PEMBAHASAN}

Penelitian ini secara utama membahas tentang bagaimana strategi komunikasi pemasaran dilakukan oleh pihak Pemerintah Desa Pokak, Ceper, Klaten, dalam pengelolaan objek wisata Tirta Sinongko, khususnya untuk menarik wisatawan. Secara konseptual, landasan teori yang digunakan untuk membatasi lingkup penelitian merujuk pada strategi komunikasi pemasaran dalam upaya meningkatkan kunjungan wisatawan.

Objek wisata Tirta Sinongko adalah salah satu objek wisata mata air alami dengan segmentasi semua umur, yang terletak di Desa Pokak, Kecamatan Ceper, Kabupaten Klaten. Dahulu, Tirta Sinongko digunakan oleh masyarakat sebagai saluran irigasi persawahan. Namun saat ini, sendang di Tirta Sinongko dimanfaatkan sebagai objek wisata khas di Kabupaten Klaten, yang mana sebelumnya dibangun atas dasar usulan masyarakat dan disetujui oleh Pemerintah Desa Pokak, serta diresmikan oleh Plt Bupati Klaten pada saat itu, Sri Mulyani.

Keberadaan Tirta Sinongko dapat dikatakan sebagai bentuk tindak lanjut dari Perda Kabupaten Klaten Nomor 16 Tahun 2016 tentang Rencana Kerja Pemerintah Daerah Kabupaten Klaten Tahun 2017. Selanjutnya, adanya potensi pengembangan wilayah dilakukan sebagaimana diatur dalam Pasal 21 Perda Nomor 11 Tahun 2011 tentang RT/RW Kabupaten Klaten tahun 2011-2030, dimana pengembangan wilayah Kabupaten Klaten akan diarahkan dengan menyesuaikan pola ruang yang merujuk pada kawasan lindung dan budidaya. Dalam hal ini, Tirta Sinongko menjadi salah satu upaya operasional yang dapat digunakan untuk menunjukkan adanya 


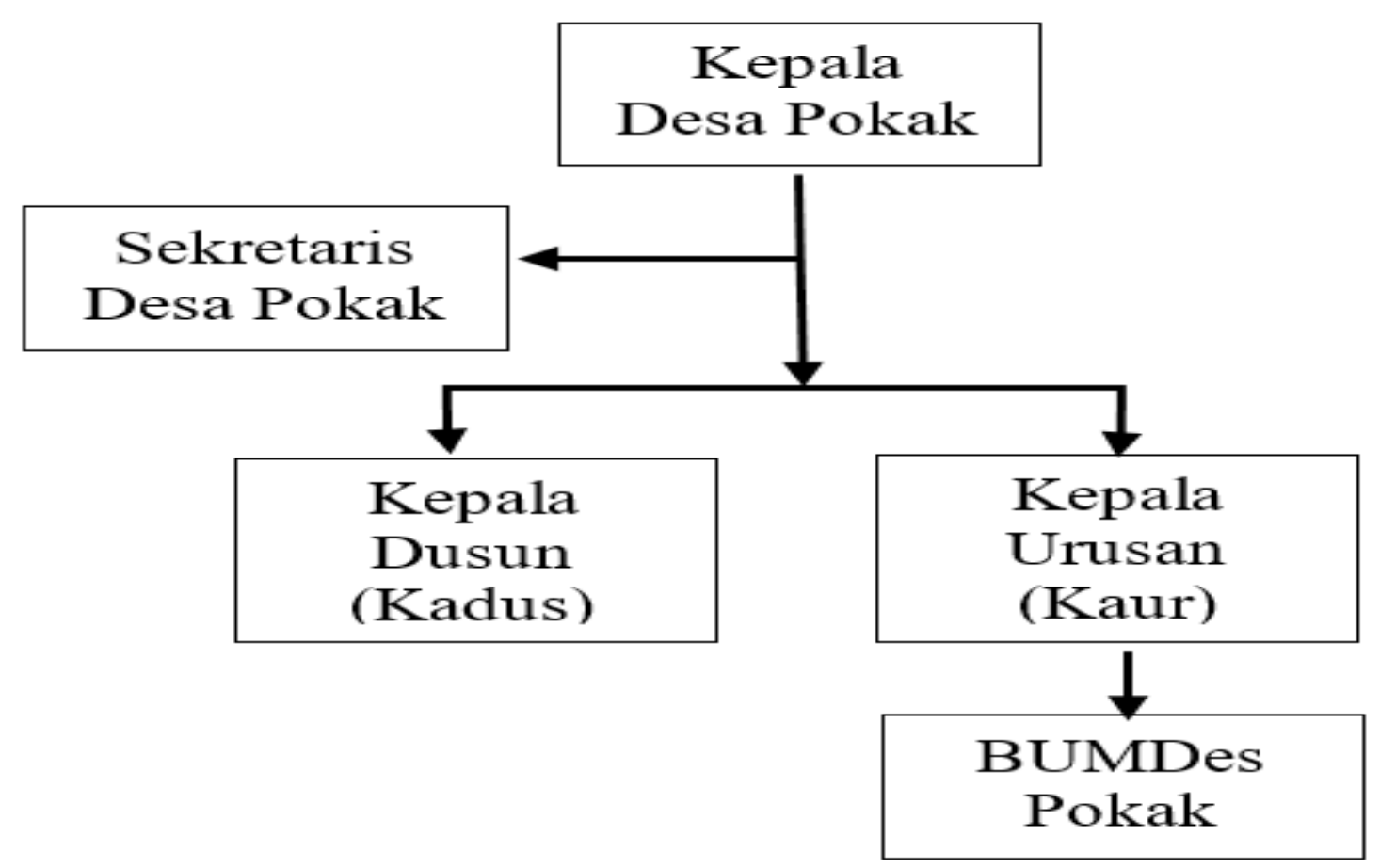

Sumber: Data Pemerintah Desa Pokak, 2018

Gambar 1 Struktur Organisasi Pemerintah Desa Pokak dan BUMDes Pokak sebagai pengelola Tirta Sinongko

keunikan lokal serta kekayaan alam atas potensi wisata di Kabupaten Klaten.

Pengelolaan objek wisata lokal Klaten, salah satunya Tirta Sinongko, dibantu oleh Badan Usaha Milih Desa (BUMDes). BUMDes adalah badan usaha bentukan Pemerintah Desa, yang mana sebelumnya muncul berdasarkan arahan dari pemerintah Kabupaten Klaten untuk mengoptimalkan sumber daya wisata di Kabupaten Klaten. BUMDes sebagai bagian dari pengelolaan Tirta Sinongko bertugas sebagai pelaksana operasional yang anggotanya terdiri dari warga masyarakat dan karang taruna (pemuda).

Secara organisasional, struktur organisasi dari pengelola Tirta Sinongko, dapat dilihat pada gambar 1 .

Melalui struktur organisasi pada gambar 1, dapat dilihat bahwa keberadaan BUMDes sebagai pengelola teknis dan operasional Tirta Sinongko berada di bawah struktur Kaur (Kepala Urusan). Secara spesifik, teknis kerja dari BUMDes sebagai pengelola operasional, berjalan sesuai dengan arahan dari Pemerintah Desa, yang dalam hal ini adalah Kepala Desa Pokak sebagai konseptor program yang utama.

Penelitianlapangan dilakukandi Pemerintah Desa dan objek wisata Tirta Sinongko. Pengumpulan data dilakukan secara langsung kepada Kepala Desa Pokak, yaitu Soetjiati, S. 
Pd., dimana informasi yang diperoleh berkaitan dengan konsep dan kebijakan pemasaran Tirta Sinongko, serta bagaimana perencanaan strategi komunikasi pemasaran yang dilakukan untuk mengoptimalkan wisatawan yang berkunjung ke Tirta Sinongko.

Selanjutnya, Koordinator BUMDes, Aditomo, juga menjadi informan dalam penelitian ini, terutama untuk keperluan data mengenai pengelolaan Tirta Sinongko sebagai objek wisata dan kerjasama serta pembagian jobdesk atas pengelolaan pemasaran Tirta Sinongko bersama Pemerintah Desa. Terakhir, sumber data melalui wawancara juga dilakukan kepada informan, Widodo, selaku anggota paguyuban masyarakat dan perwakilan BUMDes guna menguatkan informasi dan data mengenai tugas serta pelaksanaan teknis atas pengelolaan pemasaran Tirta Sinongko.

Keberadaan Tirta Sinongko secara sekilas dapat dikatakan sebagai salah satu indikator bagi Kabupaten Klaten yang secara khusus dilakukan pada Desa Pokak, Ceper untuk mewujudkan konsep pariwisata desa. Dalam hal ini, aspek pariwisata desa merujuk pada bentuk desa wisata yang terdiri dari integrasi antara atraksi, akomodasi, serta fasilitas pendukung yang disajikan dalam struktur kehidupan masyarakat yang menyatu dengan tradisi masyarakat tersebut. Selain itu, konsep desa wisata mengarah pula pada bagaimana sebuah desa mampu memiliki kecenderungan untuk menjadi kawasan pedesaan yang khas dan berdaya tarik untuk tujuan wisata (Dini \& Susi, 2016)

Sejumlah faktor yang dapat diklasifikasikan terkait dengan konsep desa wisata, antara lain adalah: 1) faktor kelangkaan; 2) faktor kealamiahan; 3) keunikan; dan 4) faktor pemberdayaan masyarakat (Prakoso, 2008). Dalam konteks ini, Tirta Sinongko merupakan objek wisata yang paling tidak memiliki dan memenuhi sejumlah faktor di atas, yaitu faktor kealamiahan yang merujuk pada Tirta Sinongko sebagai sumber mata air alami di Kabupaten Klaten, serta faktor pemberdayaan masyarakat yang mampu mengoptimalkan daya kerja masyarakat untuk pengelolaan Tirta Sinongko sebagai objek wisata khas di Desa Pokak melalui Pemerintah Desa dan BUMDes.

Mengenai eksistensi Tirta Sinongko dibandingkan dengan sejumlah objek wisata lain yang ada di Kabupaten Klaten, pada dasarnya Tirta Sinongko sebagai bentuk pemanfaatan objek wisata saat ini perlu melakukan sejumlah upaya pemasaran dan promosi. Mengingat dahulunya, Tirta Sinongko memiliki pandangan image atau reputasi yang identik dengan wilayah wingit dan kurang baik di mata masyarakat, maka dalam perkembangannya, objek wisata Tirta Sinongko perlu menyelaraskan promosi untuk tidak sekedar menjadi objek wisata yang 
berbeda, melainkan turut memunculkan citra lain yang baik secara sosial di mata masyarakat.

Pernyataan di atas pada dasarnya sejalan dengan unsur-unsur dalam objek penawaran produk pariwisata yang dijelaskan yang meliputi: 1) daya tarik tujuan wisata; 2) fasilitas objek wisata; dan 3) kemudahan untuk mencapai tujuan wisata (Seno, 2010). Secara nyata, salah satu aspek, yakni daya tarik tujuan wisata, menjadi aspek penting dalam menentukan bagaimana objek wisata memiliki citra yang baik di mata masyarakat. Dalam konteks ini, operasionalisasi Tirta Sinongko sebagai objek wisata lokal Klaten pada akhirnya turut mempengaruhi bagaimana citra ataupun image Tirta Sinongko berubah menjadi lebih baik.

Selanjutnya, berbicara mengenai komunikasi pemasaran, secara konseptual komunikasi pemasaran dimaknai sebagai pertukaran informasi dua arah dan persuasi yang mendukung sebuah proses pemasaran sehingga dapat bersifat lebih efektif dan efisien (Suryanto, 2015). Selain itu, guna membujuk, mempersuasi, memberikan informasi, serta mengingatkan konsumen terhadap produk yang ditawarkan oleh perusahaan, maka komunikasi pemasaran sangat dibutuhkan baik yang dilakukan secara langsung maupun tidak langsung (Kotler \& Keller, 2009).

Terdapat dua aspekutama dalamkomunikasi pemasaran, yakni: periklanan dan promosi.
Terkait tujuannya, komunikasi pemasaran juga berkenaan dengan fungsi informasi, persuasi, serta reminder (pengingat kembali). Lebih jelas, spesifikasi dalam menjelaskan konsep komunikasi pemasaran dapat diwakili dengan beberapa hal ini, yakni: 1) Public Relations; 2) personal selling; 3) promosi penjualan; 4) online marketing; dan 5) periklanan (Suryanto, 2015).

Terkait dengan jenis komunikasi pemasaran yang dijelaskan oleh Kotler secara spesifik tersebut, aspek Public Relations (PR) menjadi salah satu bahasan di dalamnya. PR dalam konteks ini dinyatakan oleh Internasional Public Relations Associations (IPRA) sebagai salah satu fungsi manajemen yang direncanakan sekaligus berkelanjutan melalui organisasi dan lembaga swasta ataupun publik, terutama untuk memperoleh simpati dan dukungan dari publik terhadap kepercayaan mereka atas perusahaan.

PR dalam pengertian sederhana dinyatakan berkaitan erat dengan fungsi dan kegiatan komunikasi, terutama identik dengan komunikasi yang bersifat dua arah (two way communications) (Soemirat \& Ardianto, 2005). Pemahaman ini menjelaskan bahwa PR pada dasarnya mengutamakan adanya komunikasi secara penuh dalam sebuah organisasi (Michnik, 2015). Adapun komunikasi dalam hal ini dirasa penting ketika informasi yang mengalir dalam sebuah tubuh lembaga berkaitan 
bahkan bertalian dengan adanya kekuatan dalam lembaga tersebut (Ofuani, Sulaimon, \& Adebisi, 2018; Paul, 2016; Nguru, 2018). Sebut saja salah satunya, bahwa komunikasi dalam konteks ini penting untuk membentuk sekaligus membangun adanya relasi antara media, praktisi PR, serta lembaga ketiga lainnya (Adagala \& Michael, 2017).

Selain merujuk pada fungsi komunikasi dan manajemen, PR juga dapat digunakan dalam fungsi bisnis, salah satunya pada apa yang disebut sebagai marketing public relations. PR dalam kepentingan marketing atau pemasaran digunakan secara spesifik untuk mencapai beberapa sasaran, yaitu: 1) memperkenalkan produk perusahaan; 2) membantu meningkatkan suatu produk; 3) mencari dan memperluas pangsa pasar produk; 4) mengukuhkan atau menguatkan image (citra) positif produk (Soemirat \& Ardianto, 2005).

Terkait dengan pelaksanaan komunikasi pemasaran di Tirta Sinongko, bagaimana komunikasi pemasaran dilakukan serta direncanakan secara strategis pada dasarnya tidak terlepas dari sejumlah prinsip pemasaran dan kehumasan yang telah dijelaskan secara konseptual di atas. Dalam upayanya, komunikasi pemasaran yang secara khusus dilakukan memungkinkan adanya pelaksanaan komunikasi dua arah antara komunikator (pihak pengelola Tirta Sinongko) dengan komunikan (pengunjung atau wisatawan).

Selebihnya, komunikasi pemasaran yang dimunculkan juga tidak terlepas dari aspek image baik yang dimunculkan untuk mengemas Tirta Sinongko sebagai salah satu objek wisata alami khas Kabupaten Klaten. Sebagai follow up, adanya image yang baik mengenai Tirta Sinongko pada akhirnya juga turut berpengaruh terhadap daya kunjung wisatawan yang ada dalam objek wisata tersebut.

Secara garis besar, ditemukan data mengenai bentuk strategi komunikasi pemasaran yang dilakukan oleh Tirta Sinongko dalam lingkup teknis dan operasional yang merujuk pada beberapa hal, yakni: 1) promosi internet; 2) promosi melalui event atau kegiatan; dan 3) penjualan melalui ticketing. Sejumlah strategi ini dilakukan melalui kerjasama dari Pemerintah Desa Pokak sebagai konseptor utama program, yang selanjutnya dilakukan secara operasional melalui BUMDes bentukan Pemerintah Desa, yang beranggotakan masyarakat serta karang taruna Desa Pokak.

Untuk promosi internet, komunikasi pemasaran pertama yang dilakukan ini adalah melalui penggunaan media sosial dari Tirta Sinongko, seperti Facebook dan Instagram. Adapun promosi internet ini tergolong dalam bentuk pemasaran interaktifyang memanfaatkan media digital dalam penyampaian pesan informasinya. 
Adapun penggunaan media sosial Instagram dapat dilihat melalui akun @ sendangsinongko dengan nama Sendang Tirto Sinongko. Sedangkan promosi melalui platform Facebook dapat dilihat dalam nama akun yang sama, yakni Sendang Tirto Sinongko, dapat dilihat pada gambar 2. Lebih lanjut, penggunaan media sosial ini salah satunya bertujuan untuk membagikan sejumlah informasi dan gambaran mengenai objek wisata Tirto Sinongko, selain juga menjadi media publikasi interaktif agar dapat diakses secara lebih mudah oleh masyarakat di manapun dan kapanpun.

Penggunaan media sosial ini dimaksudkan untuk lebih mempromosikan Tirta Sinongko sebagai salah satu objek wisata di Kabupaten Klaten. Penggunaan media sosial ini pada dasarnya dilatarbelakangi oleh kurangnya wisatawan yang datang ke Tirta Sinongko sejak pembangunannya kembali tahun 2016. Hal ini dapat dilihat dari salah satu statement yang disampaikan oleh Kepala Desa Pokak, Soetjiati. "Kalau dibandingkan dari awal dibangun hinggasaatinipengunjungsudahbertambah, dan saat ini kami masih melakukan upaya untuk menarik pengunjung sebanyakbanyaknya".

Adanya media sosial sebagai bagian dari platform internet pada akhirnya masih menjadi alternatif promosi murah yang dilakukan oleh sejumlah objek wisata. Hal ini didasari sejumlah riset yang selaras dengan bagaimana internet

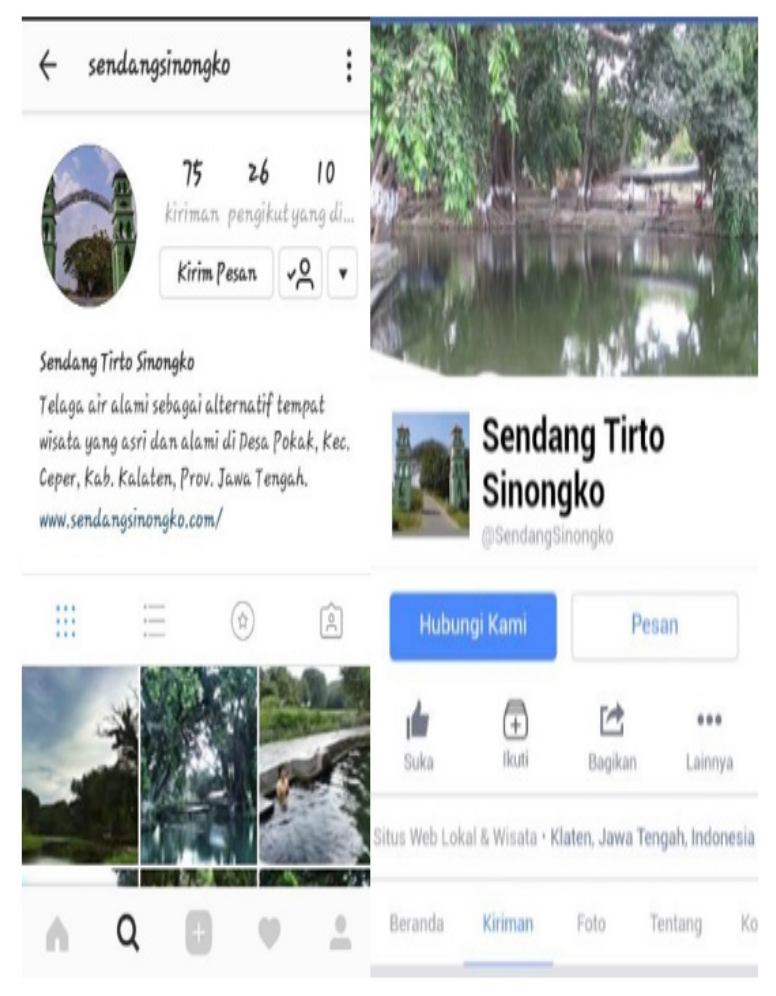

Sumber: Akun Instagram dan Facebook Tirto Sinongko Sinongko, 2018

Gambar 2 Media sosial Instagram dan Facebook Tirta Sinongko

menjadi dasar baru dalam pemanfaatan media komunikasi dan seluruh bidang lainnya. Sebut saja antara lain dalam penggunaan internet (Yanti \& Yusnaini, 2018) dalam e-learning (Knox, 2014; Hidayat, 2017), e-commerce (Astuti \& Nasution, 2014; Ardiansyah, Yunizar, \& Harsanto, 2016), e-procurement (Aprizal \& Purba, 2013; Harjito, Achyani, \& Payamta, 2015), e-voting (Kahani, 2006; Hilbert, 2009), serta $e$-health (Coleman, 2014; Wentink, Prieto, de Kloet, Vliet Vlieland, \& Meesters, 2017).

Adapun upaya untuk menarik pengunjung yang banyak dilakukan dengan membuat akun media sosial Facebook dan Instagram. Upaya 
ini merupakan upaya pemasaran interaktif yang secara khusus dikemas melalui media internet. Pengelolaan akun media sosial ini dilakukan oleh anggota paguyuban karang taruna sebagai bagian dari BUMDes dengan mengunggah beberapa postingan informasi mengenai Tirta Sinongko. Melalui media sosial tersebut, sejumlah kegiatan di Tirta Sinongko juga dapat di blow up dan diviralkan melalui media sosial. Hal ini sejalan dengan pendapat dari Widodo, anggota Paguyuban Masyarakat serta Aditomo, Ketua BUMDes Pokak.

"Kalau media sosial itu yang membuat dari paguyuban karang taruna, karena yang lebih mengerti tentang media sosial Facebook dan Instagram, baik sih adanya media sosial itu dapat mengenalkan Tirta Sinongko ke masyarakat".

"Memang ada pemasaran melalui internet, dan memang dengan adanya pemasaran melalui Facebook dan Instagram itu jumlah pengunjung mengalami kenaikan dan melalui media sosial itu juga kami juga mendapat masukan tentang Tirta

Sinongko".

Pada dasarnya, salah satu sifat khas dari internet sebagai media yang digunakan untuk berkomunikasi adalah interaktif. Sifat interaktif pada internet merupakan konsep yang jelas membedakannya dengan media konvensional lainnya.

Karakter interaktif pada internet menurut Graham mengarahkan internet untuk mempermudah penggunanya dalam berkomunikasi dan berinteraksi satu sama lain. Internet secara tidak langsung mampu mewakili kehadiran dan keterlibatan fisik antar sesama penggunanya saat berkomunikasi. Hal inilah yang selanjutnya mengamini pendapat Shawn Wilbur bahwa fasilitas web dapat memungkinkan adanya ethereal contact sehingga seseorang akan menemukan efek dalam kehidupannya ketika berkomunikasi di dalam cyberspace (Nasrullah, 2014).

Merujuk pada pendapat di atas, Gibson memaknai cyberspace sebagai sebuah concencual hallucination. Sedangkan Bromberg memaknai ruang siber sebagai "non-linier reality of mind-altering-drugs" atau realitas nonlinier dari sebuah obat yang mampu mengubah pikiran. Namun demikian, secara keseluruhan, konsep ruang siber ini dapat dijelaskan sebagai ruang konseptual, dimana seluruh kata, relasi antar individu, data, kesejahteraan, bahkan kekuatan dapat dimanifestasikan oleh setiap orang dan terhubung melalui teknologi berbasis

\section{Computer Mediated Communication (CMC)} (Nasrullah, 2018).

Menanggapi pemahaman di atas, bagaimana individu pada akhirnya dapat menemukan efek tertentu ketika berkomunikasi di dunia siber selanjutnya berimplikasi pada munculnya bentuk masyarakat (komunitas) virtual, yang mana memiliki karakteristik tersendiri dalam pola komunikasinya. Hal ini disebabkan karena bentuk komunitas virtual juga turut 
disertai dengan kemunculan konsep budaya virtual (cyberculture) yang memungkinkan setiap individu mampu untuk berinteraksi dan berkomunikasi dengan cara tersendiri dengan basis media internet sebagai platform utamanya.

Sehubungan dengan penelitian ini, adapun penggunaan promosi dan pemasaran melalui media internet ini dirasa memiliki keuntungan yang lebih dibandingnya dengan promosi yang dilakukan secara konvensional. Pemasaran internet adalah pemasaran yang menggunakan teknologi internet sebagai saluran penyampaian informasi, dilakukan secara serempak dan ditujukan untuk banyak orang secara bersamaan. Beberapa alasan penggunaan media internet sebagai sarana pemasaran dinyatakan oleh pengelola karena memiliki biaya yang lebih murah serta dapat memuat informasi yang lebih besar (Hermawan, 2012b).

Merujuk pada pemanfaatan promosi yang dapat lebih optimal dilakukan melalui internet, salah satu penelitian terdahulu yang dilakukan oleh Difa Nurhasna Ayutiani dan Berlian Primadani Satria Putri tentang Penggunaan Akun Instagram sebagai Media Informasi Wisata Kuliner. Dalam penelitiannya yang bersifat etnografi virtual, penggunaan akunInstagram@Kulinerbandung sebagai media informasi kuliner di wilayah Bandung nyatanya mampu memberikan perubahan dalam sejumlah respon followers Instagram yang mendapatkan informasi di dalamnya, baik respon kognitif, afektif, maupun behavioral. Outputnya adalah bahwa secara behavioral, para followers selanjutnya melakukan wisata kuliner dan memberikan informasi kembali pasca melihat unggahan pada akun Instagram @ Kulinerbandung (Ayutiani, Primadani, \& Putri, 2018).

Hal yang sama juga terjadi pada penggunaan media Instagram dan Facebook sebagai sarana pemetaan konten promosi digital pada bisnis kuliner Kika s Catering. Melalui penelitian Yuni Tresnawati dan Kurniawan Prasetyo ini, terdapat sejumlah hal yang perlu diperhatikan dalam melakukan kegiatan promosi digital, yakni terkait segmentasi dan pengisian informasi atau konten promosi. Dalam Instagram, konten yang sesuai lebih diarahkan pada bentuk visual dan hashtag, sedangkan dalam Facebook, konten yang disampaikan lebih merujuk pada bentuk teks, foto album, serta fanpage (Tresnawati \& Prasetyo, 2018)

Berdasarkanuraiandiatas, dapatdisimpulkan bahwa penggunaan internet nyatanya bukan tanpa alasan. Bagaimana efek dan pemaknaan yang dimunculkan atas penyampaian pesan melalui internet tak terkecuali media sosial nyatanya mampu memberikan efek interaktif bagi setiap penggunanya. Dengan demikian, adanya promosi Tirta Sinongko yang dilakukan melalui digital pada akhirnya mampu menarik 
perhatian masyarakat agar berkeinginan untuk mengunjungi objek wisata Tirta Sinongko.

Selanjutnya, bentuk komunikasi pemasaran kedua yang dilakukan di Tirta Sinongko adalah penyelenggaraan event atau kegiatan khusus. Adapun penyelenggaraan event ini merujuk pada event tahunan Tirta Sinongko, salah satunya event Bersih Sendang Tirta Sinongko. Event ini dahulunya merupakan kegiatan yang berkaitan dengan budaya "kenduri" di Sendang Tirta Sinongko. Dalam hal ini, kegiatan tersebut pada akhirnya menjadikan image Tirta Sinongko menjadi lokasi tempat yang cenderung angker dan jarang dijamah manusia.

Kondisi Tirta Sinongko secara alamiah sebenarnya merupakan sebuah mata air (sendang). Di dalamnya terdapat sejumlah kolam yang memang dimanfaatkan untuk irigasi bagi masyarakat sehingga sebagai bentuk penghormatan dan rasa syukur atas hasil panen pertanian yang melimpah, maka sendang yang dahulunya dimanfaatkan untuk irigasi ini kemudian diperingati melalui hari jadi Tirta Sinongko, sekaligus mempromosikan Tirta Sinongko sebagai sebuah objek wisata kepada masyarakat.

\section{Pelaksanaan event Tirta Sinongko} berlangsung dalam waktu beberapa hari. Event kegiatan ini pada dasarnya secara signifikan dapat menarik perhatian masyarakat sehingga banyak wisatawan yang berkunjung ke lokasi.
Misalnya saja, ketika puncak event berlangsung, yakni hari ketiga event, yang mana diisi dengan menyembelih hewan ternak dari masyarakat dan dimasak serta dibagi secara massal sekaligus gratis bagi wisatawan yang datang. Selain itu, adanya pentas seni sebagai hiburan yang melibatkan masyarakat sekitar dalam pelaksaaan event malam harinya, menjadi salah satu daya tarik Tirta Sinongko bagi para wisatawan. Hal tersebut dijelaskan oleh Widodo selaku anggota dari Paguyuban Masyarakat.

"Dalam penyelenggaraan event itu semua terlibat dalam mengisi acara, hari pertama itu kirab budaya diisi semua masyarakat dan sekolah-sekolah, instansi nah hari kedua kami dibantu masyarakat menyiapkan event puncaknya, nah hari kedua merupakan acara sembelih hewan itu dan malamnya acara pentas seni ketoprak yang diisi dari masyarakat setempat".

Pelaksanaan event di Tirta Sinongko pada dasarnya dapat terlaksana atas kerjasama sejumlah pihak. Adapun kerjasama dari pihak Pemerintah Desa, BUMDes, dan masyarakat secara umum, dilakukan untuk kelancaran event Tirta Sinongko. Selain itu, adanya dukungan dari Pemerintah Kabupaten juga dapat terlihat pada masuknya event Bersih Sendang Tirta Sinongko pada kalender event Kabupaten Klaten, sebagaimana disampaikan oleh Aditomo:

"Jadi kalo periklanan memang kita tidak melakukan, tapi dibantu Kabupaten dalam menyebarkan iklan. Karena event bersih sendang sudah dimasukkan di kalender event nya Klaten itu artinya event ini 
memiliki potensi yang baik”.

"Iya betul, soalnya kan ini sudah dikemas oleh Kabupaten bahwa memang setiap tahunnya diadakan event ini dan ada pembagian makanan gratis bagi seluruh wisatawan yang datang sehingga ketika acara ini berlangsung banyak masyarakat yang datang untuk menyaksikan dan melalui event ini menjadi icon Tirta Sinongko".

Pada dasarnya penyelenggaraan event ataupun kegiatan pada suatu lembaga maupun institusi biasanya dilakukan secara khusus oleh pihak humas atau PR dari lembaga terkait. Secara sekilas, event dilaksanakan untuk memperkenalkan suatu produk kepada masyarakat sekaligus mempromosikan produk tertentu melalui kegiatan khusus. Event tidak hanya merujuk pada kegiatan biasa, melainkan kegiatan yang memiliki nilai khusus yang menjadi pembeda atas produk yang disampaikan.

Menilikpadasejumlahpernyataaninforman, adanya kegiatan khusus yang dilaksanakan di Tirta Sinongko pada akhirnya digunakan untuk memperkenalkan Tirta Sinongko sebagai sebuah objek wisata yang mana memiliki image yang berbeda dengan sebelumnya. Pelaksanaan event ini juga mengikutsertakan masyarakat untuk berpartisipasi di dalamnya sehingga memunculkan citra bahwa Tirta Sinongko adalah objek wisata lokal semakin yang dekat dan identik dengan masyarakat. Kedekatan inilah yang selanjutnya diharapkan dapat menciptakan persepsi baik atas keberadaan Tirta Sinongko di mata masyarakat sehingga semakin banyak wisatawan yang berkunjung ke lokasi tersebut.

Sedikit berkenaan dengan analisis sebelumnya, promosi adanya event di Tirta Sinongko juga dipasarkan melalui media sosial. Brogan menjelaskan bahwa media sosial adalah perangkat baru dalam bidang komunikasi yang berkolaborasi dan mampu melahirkan banyak interaksi secara dua arah (Oktaviani \& Rustandi, 2018). Dalam konteks ini, promosi event Tirta Sinongko juga dilakukan melalu media sosial, salah satunya Facebook yang mana pada akhirnya dapat mendukung digital marketing dalam upaya strategi pemasaran Tirta Sinongko.

Berikut adalah salah satu bentuk informasi yang dibagikan melalui akun media sosial Facebook Tirto Sinongko yang berkenaan dengan kegiatan Bersih Desa Sendang Tirto Sinongko. Sekilas acara ini dilakukan layaknya acara bersih desa di tempat yang lainnya. Namun demikian, pelaksanaan Bersih Desa Sendang Tirto Sinongko sengaja dikonsep secara lebih masif dengan menyertakan warga sekitar untuk turut andil menyemarakkan kegiatan sehingga esensi kegiatan menjadi lebih menarik perhatian masyarakat. Dengan menyebarluaskan informasi mengenai kegiatan 
ini, secara tidak langsung hal tersebut mampu mendukung publikasi sekaligus promosi event bagi objek wisata Tirto Sinongko, pada gambar 3.

Selain melakukan promosi event dengan menggunakan media sosial, pengelola Tirta Sinongko juga melakukan pemasaran dengan menjalin komunikasi dengan media (media relations). Sebut saja sejumlah media online seperti: solopos.com, kompas.com, serta sorot. klaten.com.

Adapun upaya dalam media relations, secara teoritis dapat dilakukan melalui beberapa bentuk kegiatan, antara lain adalah konferensi pers, press gathering, kunjungan media, serta press up grading (Sambo, 2019). Namun demikian, pelaksanaan media relations terkait pemasaran Tirto Sinongko ini lebih kepada kerjasama dalam membuka relasi serta memberikan kesempatan terbuka bagi para jurnalis yang datang ke Tirto Sinongko untuk meliput sejumlah kegiatan sehingga mendukung keberadaan Tirto Sinongko sebagai salah satu objek wisata yang mampu menjadi alternatif bagi masyarakat, khususnya di area Klaten dan Soloraya.

Adanya upaya Pemerintah Desa Pokak sebagai pengelola Tirta Sinongko pada dasarnya dibarengi dengan kesadaran mereka atas pentingnya menjalin relasi dengan media sekitar untuk upaya pemasaran Tirta Sinongko.

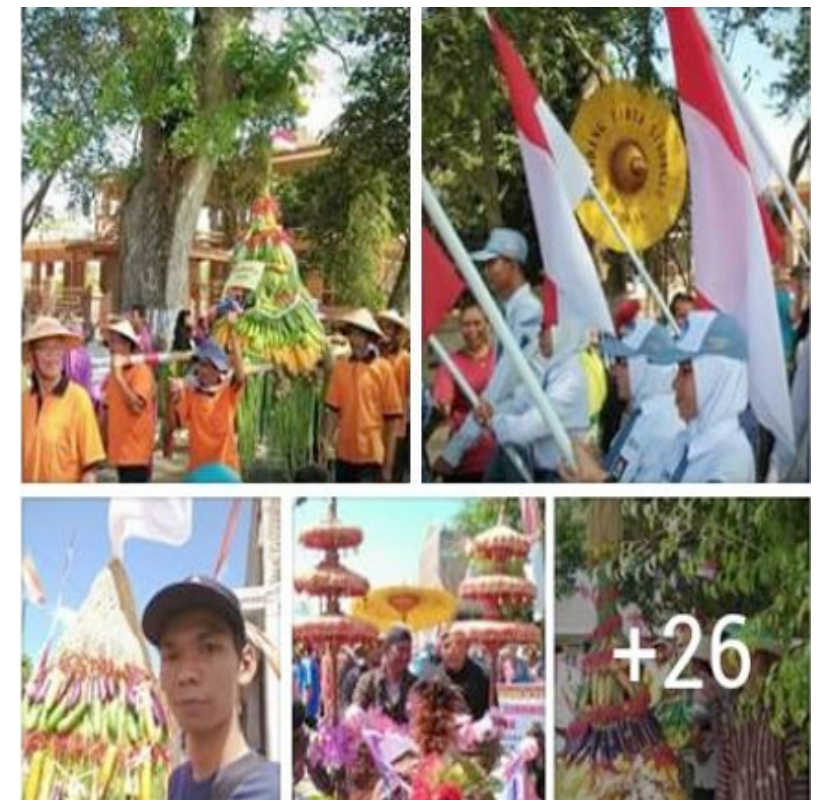

Sumber: Akun Facebook Tirto Sinongko Sinongko, 2018

Gambar 3 Event Bersih Sendang Tirta Sinongko

Hal ini disampaikan langsung oleh Kepala Desa

Pokak, Soetjiati.

“...memberikan informasi yang diperlukan, kami berusaha memberikan informasi yang jelas. Banyak wartawan yang kesini terutama pada saat event tapi dengan begitu sangat terbantu kami”.

Menjalin relasi dengan pers dirasa memiliki dampak positif bagi kelangsungan hidup sebuah objek wisata. Hal inilah yang selanjutnya menjadi salah satu acuan bagi Pemerintah Desa dan BUMDes Pokak untuk terus mengembangkan Tirta Sinongko sebagai objek wisata yang dikenal masyarakat melalui kerjasama dengan media.

Lebih lanjut, bentuk strategi komunikasi pemasaran ketiga yang dilakukan oleh pengelola Tirta Sinongko, secara operasional merujuk 
pada penjualan dan pembelian tiket. Penjualan tiket masuk ini ditujukan untuk sejumlah wahana tertentu yang ada di Tirta Sinongko, yaitu becak air dan kolam renang anak. Adapun wahana becak air dikenakan biaya retribusi sebesar Rp 5.000,00, sedangkan kolam renang anak dikenakan biaya retribusi $\mathrm{Rp} 2.000,00$ per orang.

Nickels William menyatakan bahwa penjualan personal adalah interksi yang dilakukan antar individu secara langsung dan tatap muka guna menciptakan, memperbaiki, serta mempertahankan pertukaran yang saling menguntungkan kedua pihak (Hermawan, 2012a). Konteks penjualan personal ini pada akhirnya mengarah pada bagaimana Tirta Sinongko memanfaatkan komunikasi langsung kepada wisatawan untuk melakukan promosi secara diadik sehingga perkiraan efek dalam komunikasi pemasaran yang dilakukan akan menciptakan persuasi secara bersifat langsung pula.

Terkait dengan penjualan personal yang dilakukan, Tirta Sinongko terlebih dahulu melakukan segmentasi atas sasaran wisatawan yang dituju. Dalam menetapkan sasaran ini, Tirta Sinongko memilih jenis kelompok wisatawan keluarga, mulai dari anak-anak sampai dewasa. Hal ini sejalan dengan sejumlah fasilitas yang disediakan di Tirta Sinongko, seperti: kolam anak; kolam dewasa; pemancingan gratis; taman bermain; wahana becak air; sampai dengan wahana edukasi lainnya.

Selanjutnya, pengelola Tirta Sinongko juga melakukan "pelayanan" sebagai bentuk fasilitas non material dalam melakukan penjualan personal. Hal ini dapat ditinjau dari strategi pengelola untuk memberikan informasi, arahan, serta fasilitas keamanan dalam beberapa wahana di Tirta Sinongko. Selain itu, adanya komunikasi langsung dalam penjualan personal yang dilakukan, secara eksplisit juga dilakukan melalui proses jual beli tiket (ticketing) sebagai upaya promosi sekaligus menambah pemasukan atas pengelolaan Tirta Sinongko. Hasil dari penjualan tiket kemudian digunakan untuk keperluan perbaikan serta penambahan fasilitas. "Iya penjualan itu memang ada tapi kita baru menyediakan penjaga wahana dikasih kotak itu bagi yang mau naik wahana tersebut. Nah hasil dari penjualan itu belum masuk ke Pemerintah Desa melainkan untuk perbaikan wahana, untuk penambahan fasilitas".

Pernyataan di atas didukung oleh pendapat Aditomo selaku Ketua Pengelola BUMDes.

"Untuk penjualan tiket itu dibagi mbak ada dua retribusi yang satu di kolam anak dan yang satu di wahana becak air dan jadwalnya secara bergantian. Nah dananya itu masuk ke kas warga".

Terkait dengan sejumlah wahana yang ditawarkan di Tirta Sinongko, pada dasarnya objek wisata ini juga menawarkan beberapa wahana lain yang sengaja digratiskan bagi 
wisatawan. Misalnya saja wahana permainan anak, kolam ikan pemancingan, serta taman untuk sekedar berfoto yang cenderung digemari para remaja. Adanya wahana-wahana gratis ini secara tidak langsung mampu menjadi daya tarik tersendiri bagi keberadaan Tirta Sinongko sebagai alternatif objek wisata di Kabupaten Klaten.

"Ini kan disediakan pemancingan gratis terus ada juga permainan-permainan ada taman-taman juga yang disediakan gratis lah, itu harapannya agar wisatawan tambah tertarik, tepat juga untuk wisata keluarga".

\section{SIMPULAN}

Adanya berbagai upaya untuk melakukan strategi komunikasi pemasaran, terutama bagi sebuah objek wisata tentu sangat diperlukan. Dalam penelitian ini, diperoleh simpulan bahwa Pemerintah Desa Pokak melakukan beberapa strategi komunikasi pemasaran yang diimplementasikan dalam beberapa aktivitas, yaitu: promosi online melalui media sosial; penyelenggaraan event khusus; serta kegiatan komunikasi langsung melalui penjualan personal. Namun demikian, pemasaran Tirta Sinongko ini seharusnya dapat dilakukan secara lebih optimal lagi dengan memanfaatkan strategi komunikasi pemasaran yang lebih luas dan sesuai dengan perkembangan dari Tirta Sinongko.

Pada dasarnya, Pemerintah Desa Pokak melalui BUMDes nya menyadari bahwa digitalisasi teknologi pada akhirnya menjadikan pengaruh tersendiri bagi pengelolaan objek wisata Tirta Sinongko. Sebagai objek wisata baru yang dapat dikatakan beralih fungsi dari bentuk yang sebelumnya, pengelola Tirta Sinongko memiliki tanggung jawab tersendiri untuk memasarkan objeknya sebagai lokasi wisata yang berbeda, seiring dengan persaingan sejumlah objek wisata di Kabupaten Klaten yang sejenis.

Harapannya, strategi komunikasi pemasaran dapat dikembangkan secara lebih optimal lagi agar selanjutnya Tirta Sinongko dapat menjadi objek wisata yang lebih dikenal oleh masyarakat sehingga banyak wisatawan yang berkunjung ke lokasi tersebut.

\section{DAFTAR PUSTAKA}

Adagala, N., \& Michael, B. (2017). Effective communication taking place among the internal publics in posss: the case of Naira County, Kenya. Journal of Communication, $1(1), 1-21$.

Aprizal, A., \& Purba, J. R. T. (2013). Akuntabilitas pelayanan publik dalam pelaksanaan e-procurement di Kota Pangkalpinang. JKAP (Jurnal Kebijakan Dan Administrasi Publik), 17(1), 15-28. Ardiansyah, M. K. I., Yunizar, Y., \& Harsanto, B. (2016). Shari'ah-compliant e-commerce models and consumer trust. Al-Iqtishad: Journal of Islamic Economics, 8(2), 243-254. https://doi.org/https://doi. 
org/10.15408/aiq.v8i2.2913

Astuti, N. C., \& Nasution, R. A. (2014). Technology readiness and e-commerce adoption among entrepreneurs of SMEs in Bandung city, Indonesia. Gadjah Mada International Journal of Business, 16(1), 69-88.

Ayutiani, D. N., Primadani, B., \& Putri, S. (2018). Penggunaan akun Instagram sebagai media informasi wisata kuliner, 3(1), 39-59.

Chaffey, D., \& Ellis-Chadwick, F.(2012). Digital marketing: straetgy, implementation, and practice (5th ed.). London: Pearson Education Limited.

Coleman, A. (2014). Migration from resource based to knowledge based strategy for e-health implementation in developing countries. Journal of Communication [Delhi],5(1),1-7.https://doi.org/https://doi. org/10.108 0/0976691X.2014.11884819

Dini, P., \& Susi, S. (2016). Strategi pengelolaan Desa Wisata Giyamti, Kabupaten Wonosobo. Universitas Diponegoro.

Fadli, M. (2017). Strategi komunikasi pemasaran Pemerintah Desa Kalisari dalam mengenalkan potensi Desa (analisis kualitatif deskriptif pada pemerintah Desa Kalisari). IAIN Purwokerto.

Gunawan, I. (2013). Metode penelitian kualitatif teori dan praktik. Jakarta: Bumi Aksara.

Harjito, Y., Achyani, F., \& Payamta. (2015). Implementasi e-procurement ditinjau dari kesuksesan sistem teknologi informasi dengan menggunakan model delone dan mclean. Jurnal Ekonomi Dan Bisnis, 18(1), 61-82.

Haryati, S. G. (2015). Strategi bauran komunikasi pemasaran pemerintah desa dalam menarik wisatawan (studi kualitatif di objek wisata Umbul Ponggok, Klaten,
Jawa Tengah). UIN Sunan Kalijaga.

Herdiansyah, H. (2015). Observasi, dan focus groups sebagai instrumen penggalian data kualitatif. Jakrta: Raja Grafindo Persada.

Hermawan, A. (2012a). Komunikasi pemasaran. Jakarta: Erlangga.

Hermawan,A. (2012b). Komunikasi pemasaran. pt gelora aksara media public relations dan publisitas korporat. Jakarta: Kencana.

Hidayat, A. N. (2017). E-Learning implementation in islamic education innovation. HUNAFA: Jurnal Studia Islamika, 14(1), 17-36. https://doi.org/ https://doi. org/10.24239/jsi.v14i1.460.1736

Hilbert, M. (2009). The maturing concept of e-democracy: from e-voting and online consultations to democratic value out of jumbled online chatte. Journal of Information Technology and Politics, 6(2), 87-110. https://doi.org/https://doi. org/10.1080/19331680802715242

Kahani, M. (2006). Experiences in e-voting. Journal of E-Government, 2(3), 113-125. https://doi.org/https://doi.org/10.1300/ J399v02n03_06

Klaten, P. (2014). Data sekunder Pemda Klaten. Klaten.

Knox, J. (2014). Digital culture clash: "massive"eeducation in the e-learning and digital cultures mooc. Distance Education, 35(2), 164-177. https://doi.org/https://doi. org/10.1080/01587919.2014.917704

Kotler, P., \& Keller. (2009). Manajemen pemasaran jilid 1 edisi 13. Jakarta: Erlangga.

Kriyantono, R. (2006). Teknik praktis riset komunikasi : disertai contoh praktis riset media, public relations, advertising, komunikasi organisasi dan komunikasi pemasaran. Jakarta: Kencana. 
Michnik, J. (2015). Structural analysis of problems in public relations. Multiple Criteria Decision Making, 10, 105-123.

Nasrullah, R. (2014). Komunikasi antarbudaya di era budaya siber. Jakarta: Kencana Prenada Media Group.

Nasrullah, R. (2018). Etnografi virtual: riset komunikasi, budaya, dan sosioteknologi di Internet. Bandung: Simbiosa Rekatama Media.

Nguru, M. N. (2018). Public relations and employee performance in nigerian institution of higher learning. INFORMASI: Kajian Ilmu Komunikasi, 48(2), 267-279. https://doi.org/https://doi.org/10.21831/ informasi.v48i2.21972

Oktaviani, F., \& Rustandi, D. (2018). Implementasi digital marketing dalam membangun brand awareness, 3(1), 1-20.

Onlineindopos.id. (2018). 10 Tempat wisata di Klaten yang wajib di kunjung saat libur lebaran.

Paul, O. (2016). Employee relations strategy: implication for performance in Lagos, 3(3), 53-63. https://doi.org/https://doi. org/10.18394/ iid.28545

Personal Interview Aditomo. (2018).

Pokak, P. D. (2018). Dokumen pemerintah Desa Pokak. Klaten.

Prakoso, A. A. (2008). Pengembangan Desa wisata melalui pendekatan rute wisata kasus: Desa Wisata Srowolan, Sleman, DIY. Yogyakarta: Universitas Gadjah Mada.

Saladin, D. (2002). Intisari pemasaran dan unsur-unsur pemasaran. Bandung: Linda Karya.

Sambo, M. (2019). Media Relations Kontemporer. Jakarta: Prenadamedia Group.
Seno, A. (2010). Landasan perencanaan dan perancangan Desa Wisata Kebon Agung. Universitas Atma Jaya.

Sinongko, T. (2017). Data sekunder pengunjung Tirto Sinongko. Klaten.

Sinongko, T. (2018). Akun media sosial Facebook Tirto Sinongko. Klaten.

Soemirat, S., \& Ardianto, E. (2005). Dasardasar public relations. Bandung: Remaja Rosdakarya.

Sugiyono. (2018). Metode penelitian kuantitatif, kualitatif, dan r\&d. Bandung: Alfabeta.

Suryanto. (2015). Pengantar ilmu komunikasi. Bandung: Pustaka Setia.

Tresnawati, Y.(2018). Pemetaan konten promosi digital bisnis kuliner kika' s catering di media sosial mapping the content of digital promotion for culinary business kika ' $\mathrm{s}$ catering on social media, 3(1), 102-119.

Wentink, M. M., Prieto, E., de Kloet, A. J., Vliet Vlieland, T. P. M., \& Meesters, J. J. L. (2017). The patient perspective on the use of information and communication technologies and e-health in rehabilitation. Disability and Rehabilitation: Assistive Technology, 1-6. https://doi.org/https://doi. org/10.1080/17483 107.2017.1358302

Wibowo, K., Waluyo, H. D., \& Listyorini, S. (2013). Pengaruh kualitas produk, harga dan promosi terhadap keputusan pembelian permen tolak angin di Semarang. Diponegoro Journal of Social And Politic.

Yanti, M., \& Yusnaini. (2018). The narration of digital literacy movement in Indonesia. INFORMASI: Kajian Ilmu Komunikasi, 48(2), 243-255. https://doi.org/https://doi. org/10.21831/informasi.v48i2.21148

Yunus, U. (2019). Digital branding: teori dan praktik. Bandung: Simbiosa Rekatama Media. 